\title{
Effect of Short-Term Exposure to Heat or Cold on Muscle Protein Breakdown in Rats
}

\author{
Kunioki HaYASHi, Masahiko Hino and Yuichiro Tomita \\ Department of Biochemical Science and Technology, \\ Faculty of Agriculture, Kagoshima University,
} Kagoshima-shi 890

(Received April 22, 1992)

\begin{abstract}
Hot and cold environments are typical stressors. Stress induces secretion of glucocorticoid which is known to stimulate muscle protein breakdown. However, the effects of environmental temperature on skeletal muscle protein breakdown have been studied very little. In the present study, we examined the effects of short-term exposures to heat and cold as stressors on growth and muscle protein breakdown estimated via $\mathrm{N}^{\mathrm{T}}$-methylhistidine (3-methy $\mathrm{l}$-L-histidine; $\mathrm{MH}$ ) excretion using young male rats. Animals of the treatment group received a $4 \mathrm{hr}$ exposure to $36^{\circ} \mathrm{C}$ and $1^{\circ} \mathrm{C}$ every day for 4 days. Animals of the control group were raised in a $24^{\circ} \mathrm{C}$ environment. Growth was significantly retarded and muscle protein breakdown rates increased significantly, but temporally, via both treatments. Plasma corticosterone concentrations were higher in the treatment groups, but the effect was not statistically significant in the cold group. The results indicate that short-term exposure to heat and/or cold was perceived as a stressor thus accelerating skeletal muscle protein breakdown.
\end{abstract}

Anim. Sci. Technol. (Jpn.) 64 (2) : 101-106, 1993

Key words : stress, growth, muscle protein breakdown.

It is well known that cold environment increases and hot environment decreases the metabolic rate in muscle ${ }^{9)}$. The increased production of heat, generally referred as coldinduced thermogenesis, is achieved either by phasic muscle contraction and/or by stimulation of heat production unassociated with muscular contraction; that is, nonshivering thermogenesis. Skeletal muscle protein synthesis and breakdown may have roles in thermogenesis since the processes of both protein synthesis and breakdown require energy and part of it is liberated as heat ${ }^{2,4)}$, although it has been recently suggested that sympathetic stimulation of brown adipose tissue is potentially of greater importance for thermogenesis than is sympathetic activation of skeletal muscle $^{3,13)}$.

Anim. Sci. Technol. (Jpn.) 64 (2): 101-106
On the other hand, both cooling and heating work as stressors in animals, and thus muscle protein breakdown might be accelerated by heat and cold due to the increased secretion of glucocorticoids. It has been demonstrated that administering of catabolic doses of glucocorticoid to rats results in a stimulation in myofibrillar proteolysis in skeletal muscle $e^{6.10}$. However, the effects of cooling or heating on skeletal muscle protein synthesis and breakdown have been studied very little. It is expected that the rate of skeletal muscle protein turnover changes according to ambient temperature. However, at the initial phase of adaptation, the environmental change is thought to act as a stressor, and this may induce metabolic disorder and result in growth retardation. If so, heat production may increase 
via heat exposure as well as cold exposure.

In the present study, we examined the effects of short-term exposure to cold and heat as stressors on growth and muscle protein breakdown in rats. The rate of muscle protein breakdown was estimated via $\mathrm{N}^{\top}$-methylhistidine (3-methy1-L-histidine; $\mathrm{MH}$ ) excretion. $\mathrm{MH}$ is an amino acid formed by the posttranslational methylation of specific histidine residues on myofibrillar proteins, actin and myosin. $\mathrm{MH}$ cannot charge tRNA and therefore cannot be reutilized for protein synthesis. Because of this, and also because it does not undergo catabolism, the output of $\mathrm{MH}$ in urine has been used as an in vivo index of skeletal muscle proteolysis ${ }^{5,10,14}$.

\section{Materials and Methods}

A total of 18 rats (male Sprague-Dawley rats purchased from Charles River, Atsugi, Kanagawa, Japan) were divided into three groups after 7 days prefeeding of the experimental diet when they were 55 days old. The animals were housed in a temperature-and humidity-controlled environment with a $12 \mathrm{hr}$ light-dark cycle, and fed ad libitum during the prefeeding and 4-day experimental periods on a commercial purified diet containing $24 \%$ casein (Oriental rat diet B, Oriental Yeast Co., Tokyo, Japan) made mainly of corn starch and milk casein. Animals received exposure for 4 hrs $(9: 00-13: 00)$ a day in environments of $1 \pm 2$ (cold), $24 \pm 1$ (control) and $36 \pm 1^{\circ} \mathrm{C}$ (heat), respectively, during the 4 day experimental period, in small rooms with $55-70 \%$ humidity. Since the small rooms were ventilated and the humidity of the experimental room was controlled to be $60 \%$, the humidity of the small room was within the range indicated above. Food intake and body weight changes were recorded daily. Rectal temperature was measured every day before and after the treatment. Complete $24 \mathrm{hr}$ collections of urine were made to measure $\mathrm{MH}$ for 5 days starting $24 \mathrm{hrs}$ before the beginning of the treatment, and the urine was mixed with $1 \mathrm{~m} l$ of $5 \mathrm{M} \mathrm{HCl}$ as a preservative and stored at $-20^{\circ} \mathrm{C}$ until analysis.

The $\mathrm{MH}$ was analyzed to estimate muscle protein breakdown via the method of HAYASHI et al. ${ }^{7}$ using high-performance liquid chromatography. The HPLC system incorporated reversed-phase separation with ion-pairing, using a Zorbax ODS column $(4.6 \times 150 \mathrm{~mm})$ and post-column fluorescence derivatization with 0 -phthalaldehyde. The fractional break down rate of skeletal muscle was calculated by dividing the daily urinary $\mathrm{MH}$ output derived from skeletal muscle by the pool size of $\mathrm{MH}$, assuming that the pool size and the contribution of tissues other than skeletal muscle are not changed by experimental conditions. The pool size of $\mathrm{MH}$ in skeletal muscle is estimated to be $4.26 \mathrm{mg}$ per $100 \mathrm{~g}$ body weight since the growing rats contained $4.73 \mathrm{mg} \mathrm{MH}$ per $100 \mathrm{~g}$ body weight and $10 \%$ of it was derived from tissues other than skeletal muscle ${ }^{11 \prime}$. Total urinary $\mathrm{MH}$ was multiplied by 0.76 to estimate MH excretion originating from skeletal muscle since $76 \%$ of excreted $\mathrm{MH}$ is estimated to be from skeletal muscle ${ }^{11)}$.

At 10:00 a.m. on Day 5, animals were killed by decapitation and blood was collected to measure plasma concentrations of corticosterone. Plasma corticosterone concentration was measured via reversed-phase high-performance liquid chromatography as reported by SCOTT and DixoN ${ }^{12)}$, in a small modification using a Shimazu LC $4 \mathrm{~A}$ system. A Shimpack-ODS column $(6 \times 150 \mathrm{~mm}$, Shimazu $)$ was used. Briefly, $1 \mathrm{~m} l$ plasma, $100 \mu l \quad 0.25 \mathrm{M}$ sodium hydroxide and $7 \mathrm{ml}$ dichloromethane were vortexed for $30 \mathrm{sec}$ and then centrifuged for $10 \mathrm{~min}$ at $1300 \mathrm{~g}$. A $5 \mathrm{ml}$ aliquot of the organic layer was evaporated to dryness in reduced pressure at room temperature. The residue was dissolved in $100 \mathrm{ml}$ of eluent and $50 \mu l$ of which was injected. The recovery of CTC from the plasma was $92 \%$. The eluent system was $45 \%$ methanol in water at a flow-rate of $1 \mathrm{ml}$ min, the column temperature was $30^{\circ} \mathrm{C}$, and 


\section{Heat and Cold on Muscle Protein Breakdown}

detection wavelength was $248 \mathrm{~nm}$.

The results are reported as the mean $\pm S E$. Data were evaluated by one-way and two-way ANOVA and Duncan's multiple range tests. The Statistical Analysis System was used.

\section{Results}

Exposure to both cold and heat reduced the

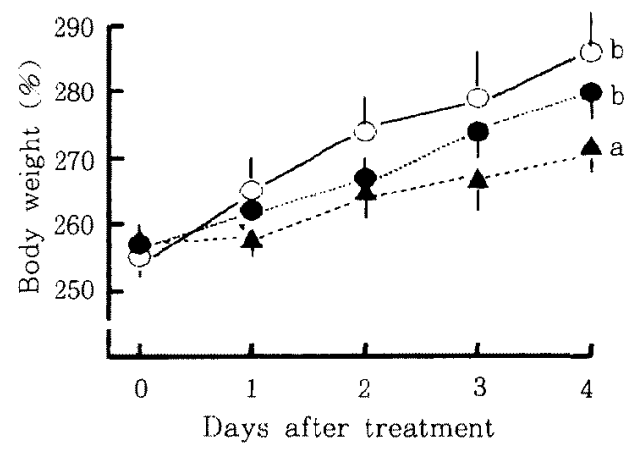

Fig. 1. Effect of exposure to heat or cold on body weight gain in rat. Animals received everyday exposure for $4 \mathrm{hr}$ to the environments of $1(\mathbf{O}), 24\left(\bigcirc\right.$, control) or $36^{\circ} \mathrm{C}(\mathbf{A})$, respectively, during the 4 days experimental period. Each datum point represents the mean \pm SE of 6 rats. Means with different superscripts are significantly different. growth rates of the animals as shown in Fig. 1. Growth depression was greater in the heat group than in the cold group. Body weight gain, feed intake and plasma corticosterone concentration are shown in Table 1. Body weight gain was reduced by $56 \%$ in the heat group and $28 \%$ in the cold group during the 4-day experimental period. Total feed intake decreased by $33 \%$ due to heat, and increased by $12 \%$ due to cold. The feed intake per unit body weight showed a similar trend, but feed efficiencies were decreased by both the heat and the cold. Plasma corticosterone concentration was increased by the heat and tended to increase due to cold on the final day of the experiment.

Time-course changes in rectal temperature measured after the treatments are illustrated in Fig. 2. Although there were no differences in rectal temperature between the groups on the first day of the treatment, the differences increased significantly by Day 2 due to heat while the cold had no effect. The ANOVA shows the significant effects of the heat and the time-course on rectal temperature.

As shown in Fig. 3, the rates of muscle protein breakdown calculated from $\mathrm{MH}$ excretions increased significantly, but temporally,

Table 1. Effect of 4 hours exposure a day to heat or cold on body weight gain, feed efficiency and plasma corticosterone concentration in rats

\begin{tabular}{|c|c|c|c|}
\hline & Control $\left(24^{\circ} \mathrm{C}\right)$ & Heat $\left(36^{\circ} \mathrm{C}\right)$ & $\operatorname{Cold}\left(1^{\circ} \mathrm{C}\right)$ \\
\hline $\mathrm{n}$ & 6 & 6 & 6 \\
\hline $\begin{array}{l}\text { Initial body weight } \\
(\mathrm{g})\end{array}$ & $256 \pm 2.8^{*}$ & $259+2.2$ & $257 \pm 2.8$ \\
\hline $\begin{array}{l}\text { Body weight gain } \\
(\mathrm{g} / 4 \text { days })\end{array}$ & $32 \pm 2.5^{\mathrm{a}}$ & $14 \pm 1.1^{b}$ & $23 \pm 1.5^{\mathrm{c}}$ \\
\hline $\begin{array}{l}\text { Feed intake } \\
\text { (g/4 days) }\end{array}$ & $67 \pm 2,6^{a}$ & $45 \pm 2.5^{b}$ & $75 \pm 2.4^{c}$ \\
\hline $\begin{array}{l}\text { (g/4 days' } \\
100 \mathrm{~g} \text { body weight) }\end{array}$ & $23 \pm 0.7^{a}$ & $16 \pm 0.7^{b}$ & $27 \pm 0.9^{c}$ \\
\hline $\begin{array}{l}\text { Feed efficiency } \\
\text { (body weight gain/ } \\
\text { feed intake) }\end{array}$ & $0.48 \pm 0.028^{3}$ & $0.30 \pm 0.015^{b}$ & $0.31 \pm 0.019^{b}$ \\
\hline $\begin{array}{l}\text { Plasma corticoster one } \\
(\mathrm{ng} / \mathrm{m} l)\end{array}$ & $59 \pm 22^{a}$ & $175 \pm 71^{\circ}$ & $127 \pm 38^{a b}$ \\
\hline
\end{tabular}

* Each value represents the mean \pm SE. Means with different superscrips are significantly different from each other $(\mathrm{P}<0.05)$. 


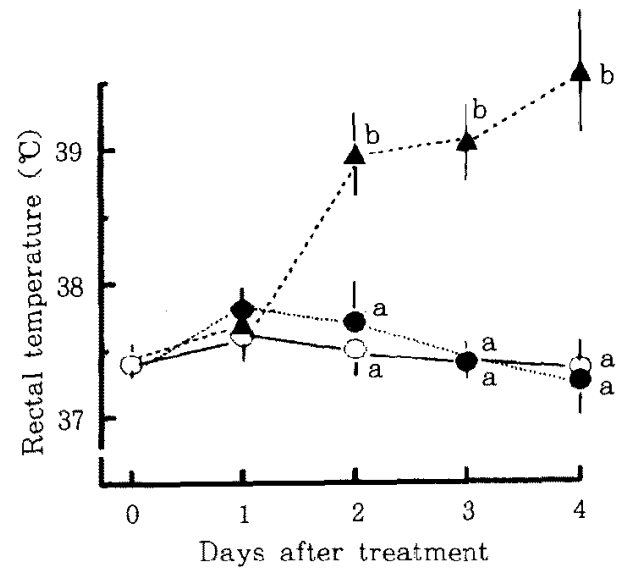

Fig. 2. Effect of exposure to heat or cold on rectal temperature in rat. Animals received everyday exposure for $4 \mathrm{hr}$ to the environments of $1(\mathbf{O}), 24\left(\bigcirc\right.$, control) or $36^{\circ} \mathrm{C}(\boldsymbol{A})$, respectively, during the 4 days experimental period. Each datum point represents the mean $\pm \mathrm{SE}$ of 6 rats. Means with different superscripts are significantly different.

via heat and cold. The ANOVA shows that the differences between groups were significant. The time-course effects of the treatments were also shown to be significant according to the ANOVA (Fig. 3). The rate of skeletal muscle protein breakdown was higher on Day 1 than on the following days in the control group, showing that the new environment itself was stressful at the beginning.

\section{Discussion}

Rats received $4 \mathrm{hrs}$ exposure a day to either heat or cold for 4 days had significant growth retardation. Feed efficiencies decreased via both treatments although feed intake was increased by the cold and decreased by the heat. These observations indicate that significant changes in metabolism were induced by exposure to a heat or a cold environment. Indeed, the rate of skeletal muscle protein breakdown increased significantly, but temporally, via both treatments, and the effect was

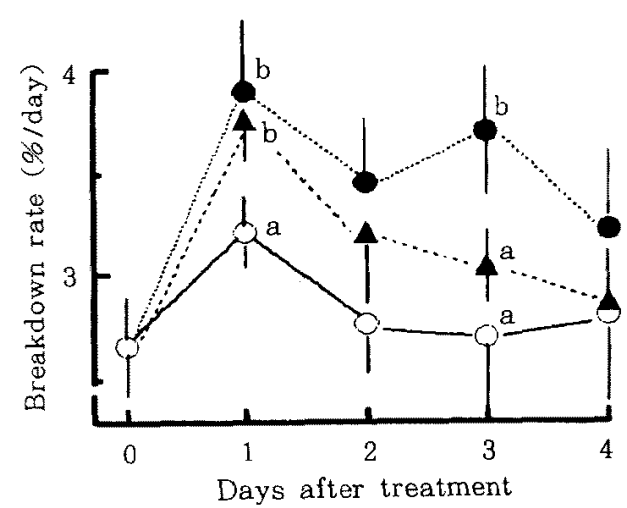

Fig. 3. Effect of exposure to heat or cold on rates of skeletal muscle protein breakdown (Kd) in rat. Animals received everyday exposure for $4 \mathrm{hr}$ to the environments of $1(\mathbf{O})$, $24\left(\mathrm{O}\right.$, control) or $36^{\circ} \mathrm{C}(\boldsymbol{\Delta})$, respectively, during the 4 days experimental period. Each datum point represents the mean $\pm \mathrm{SE}$ of 6 rats. Means with different superscripts are significantly different.

more intense when the animals were exposed to cold than to heat. However, growth was more intensely retarded when animals were exposed to a hot environment rather than a cold environment, implying that the effects on the rate of muscle protein synthesis were different. In fact, the rates of muscle protein synthesis, calculated as the sum of the rate of muscle protein breakdown and the rate of growth as reported previously ${ }^{6}$, were $6.0 \% /$ day, $5.9 \% /$ day and $5.1 \%$ /day on Day 1 of treatment for the control, cold and heat groups, respectively, and the difference between the control and heat groups was statistically significant $(p<0.05)$. The decreased rates of muscle protein synthesis by heat might be due to reduced food intake. This is not consistent with our previous observation $^{8)}$ that both the rates of muscle protein synthesis and breakdown in 27-day-old cockerels were very low under hot environments $\left(30^{\circ} \mathrm{C}\right)$ though feed intake was not significantly different between the 25 and $30^{\circ} \mathrm{C}$ environments. However, considering that the experimental 
period was long enough for the cockerels to adapt to their environment, but that, in the present experiment, the time of exposure was too short to adapt to the new environment, it is quite possible that changes in the environments adopted in the present experiment were perceived as stressors even on Day 4 of the treatment. In fact, plasma concentrations of corticosterone were more than twice those of the control in the treatment groups in the present experiment, showing that the experimental conditions were stressful. Unfortunately, we measured plasma CTC concentration only on the final day of the experiment. It is conceivable that the plasma CTC concentration might be much higher on Day 1, Day 2 and Day 3 than on Day 4. The time-dependent change in the rate of skeletal muscle protein breakdown observed in the present study is similar to the observation that chronic administration of corticosterone initially increased myofibrillar proteolysis in skeletal muscle, but that of the effect subsequently decreased ${ }^{10\rangle}$ although the mechanism of this phenomenon has not been clarified. Thyroid hormone is known to be another factor promoting skeletal muscle proteolysis. But since thyroid function declines under a hot environment, heat-induced proteolysis should be explained by factors other than thyroid hormone. Angeras et al. ${ }^{1)}$ have indicated that the increased temperature $\left(40^{\circ} \mathrm{C}\right)$ of the incubating medium potentiates muscle myofibrillar protein breakdown which has already been stimulated by sepsis using the isolated extensor digitorum longus muscle. This result is consistent with the present result. On the other hand, the rate of muscle protein breakdown is thought to be accelerated more in a cold environment than in a hot environment because thyroid hormone secretion is stimulated in a cold environment and corticosterone and thyroid hormone stimulate muscle protein breakdown synergistically ${ }^{6)}$.

There is a possibility that the heat- and cold induced increases in $\mathrm{MH}$ excretion are due to increased rates of protein breakdown of tissues containing $\mathrm{MH}$ other than skeletal muscle. However, this is unlikely because body weight changes were consistent with the changes in muscle protein breakdown.

Body temperature increased significantly due to heat exposure and the effect was far more intense on the final day of the experiment. Since protein turnover is energetically expensive, it is probable that proteolysis induced by heat exposure increases body temperature, and is followed by a change in thermoregulatory set point. Thus body temperature was higher even on Day 4 in the present experiment although protein breakdown showed decreasing trend on Day 4.

In conclusion, rats perceive short-term exposure to the heat $\left(36^{\circ} \mathrm{C}\right)$ and the cold $\left(1^{\circ} \mathrm{C}\right)$ as stressors, thus increasing muscle protein breakdown, but the effect is diminished by repeated exposure.

\section{References}

1) ANGERAS, M.H., U.L.F. Angeras, P.O. HASSELGREN and J.E. Fischer, Effects of elevated temperature on protein breakdown in muscles from septic rats. Am. J. Physiol,, 258 : C 589-C 592. 1990.

2) Bernier, J.F., C.C. Calnert and R.L. BALDWIN, Energetics of protein synthesis in mice with a major gene for growth. J. Nutr., 117 : 2036-2045. 1987.

3) Dulloo, A.G., J.B. Young and L. LANDSBERG, Sympathetic nervous system responses to cold exposure and diet in rat skeletal muscle. Am. J. Physiol., 255: E 180-E 188. 1988.

4) Goldberg, A.L., A.S. Menon, S. Goff and D.T. Chin, The mechaism and regulation of the ATP-dependent protease La from escherichiacoli. Biochem. Soc. Transac., 15: 809-811. 1987.

5) HARRIS, C.I., Reappraisal of the quantitative importance of non-skeletal-muscle source of $\mathrm{N}^{\tau}$-methylhistidine in urine. Biochem. J., 194 : 1011-1014. 1981.

6) Hayashi, K., A.G. Kayali and V.R. Young, Synergism of triiodothyronine and corticosterone on muscle protein break- 
down. Biochim. Biophys. Acta., 883 : 106111. 1986.

7) Hayashi, K., Y. MAedA, M. Toyomizu and Y. Tomit, Highperformance liquid chromatographic method for the analysis of $\mathrm{N}^{\top}$-methylhistidine in food, chicken excreta, and rat urine. J. Nutr. Sci. Vitaminol., 33: 151-156. 1987.

8) Hayashi, K., S. Kukita, M. Mukai, M. Toyomizu and Y. Tomita, Effect of dietary thyroxine on muscle protein metabolism and abdominal fat content in broiler chicken in hot and moderate environments. Jpn. J. Zootech. Sci., 61: 1107 1112. 1990.

9) JANSKY, L., Non-shivering thermogenesis and its thermoregulatory significance. Biol. Rev. 48: 85-132. 1973.

10) Kayali, M.G., M.N. Goodman, J. Lin and V.R. YounG, Insulin and thyroid hormoneindependent adaptation on myofibrillar proteolysis to glucocorticoids. Am. J. Physiol, 259 : E 699 E 705. 1990.
11) Nagasawa, T. and R. Funabikl, Quantitative determination of urinary $\mathrm{N}^{{ }_{-}}$ methylhistidine output as an index of myofibrillar protein degradation. J. Biochem., (Japan) 89:1155-1161. 1981.

12) Scott, N.R. and P.F. Dixon. Determination of cortisol in human plasma by reversed-phase high-performance liquid chromatography. J. Chromatogr., 164 : 2934. 1979.

13) Shibata, H., F. Perusse, A. Vallerand and L.J. BukowteckI, Cold exposure reverses inhibitory effects of fasting on peripheral glucose uptake in rats. Am. J. Physiol., 257 : R 96-R 101. 1989.

14) Young, V.R., S.D. Alexis, B.S. Baliga, H.N. Munro and W.Muecke, Metabolism of administered 3-methylhistidine. Lack of muscle transfer ribonucleic acid charging and quantitative excretion as 3-methylhistidine and its $\mathrm{N}$-acetyl derivative. $J$. Biol. Chem., 247 : 3592-3600. 1972.

\title{
骨格筋蛋白質分解に対する高温掞よび低温暴露の影響
}

\section{林 國舆・日野雅彦・富田裕一郎}

鹿児岛大学農学部，鹿児島市 890

\begin{abstract}
動物がストレス在受けると副腎皮質ホルモン分必が增加する。副㹂皮質ホルモンは格筋蛋白質の分 解老促進する。したがって、ストレスを受けた動物の等格筋蛋白質分解はえ進していると予想される。

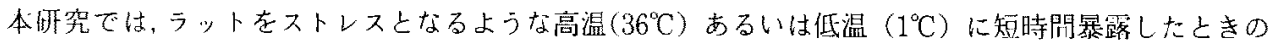
岁格筋蛋白質分解速度の変化を調べた。動物は， $36^{\circ} \mathrm{C}$ 㧍よび $1^{\circ} \mathrm{C}$ の小室在用いて，それぞ㮽日 4 時

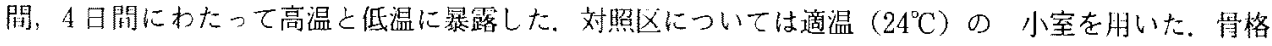
符蛋白質分解速度は $\mathrm{N}^{t}$-メチルヒスチジン $(\mathrm{MH})$ 法により調べた。水と飼料は常時与えた。 その結果, 高, 低温, いずれの処理によっても成長は阻害されたが, とくに高温環境では, 飼料攝取量の減少之相 まって，著しい成長阻害が生じた４日間の增休量は対照区に対して高温区では $44 \%$ ，低温区では 72

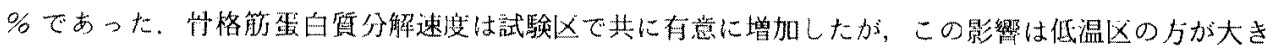
く，1日日おょび2月日においては，対照区に対して約 $20 \%$ 高い值を示した。しかし，以後いずれも

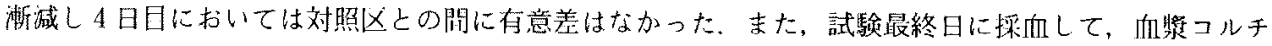
コステロンを测定したところ，試験区が共に対照区の 2 倍以上の值を示し，高温区については有意差が 認められた，以上の結果は，短時䦌の高温および低温暴露は，ストレスとして作用し，一時的に学格符 蛋白質分解を促進することを示している。
\end{abstract}

日畜会叔, $64(2): 101-106,1993$ 